a progressively diminishing share of the cake and a reputation for generosity as well.

In the circumstances, the abruptness of the decision two weeks ago must obviously be counted a departure from reason, not simply a manifestation of incompetence. In the weeks ahead, it is only natural that people should ask whether other decisions about the spending of scientific money will be dealt with in a similarly arbitrary fashion. It is important, of course, that the scientific community should not slip into the false belief that the Government should entirely abdicate its present power to intervene in the details of expenditure on scientific projects. The fact that British governments since the war have usually been willing to let their advisory committees spend what money is available without much interference is not necessarily a precedent for these times when budgets are much larger and when foreign expenditure is involved. The trouble on this occasion, however, is that the veto from on high has come like the proverbial thunderbolt out of the blue. One result is that it has done considerable damage-it remains to be seen whether the $300 \mathrm{GeV}$ machine will ever see the light of day. In the long run, however, it is much more serious that the confidence of professional scientists in the machinery for the administration of the budget has now been deeply shaken. One result will almost certainly be that the committees on which the British Government has traditionally relied for advice will become more jealous of their rights.

\section{Fewer Dollars for Research}

THE recent American tax increase and anticipated budget cuts may do much to help the economy, but they are causing American scientists to fear for their own economic future. In an attempt to avoid further budget cuts for basic research, some 400 scientists and educationists held a "erisis" meeting in New York two weeks ago organized by the New York Academy of Sciences. While the total amount of government funds for research has not yet declined-\$16.9 billion this year against $\$ 16.7$ billion last year-this does not even cover the annual 4 per cent inflationary increase and represents a sharp decline from the 22 per cent growth rate achieved during the ten years since Sputnik. With three-quarters of university research sponsored by government grants and the proportion reaching 90 per cent at such schools as Massachusetts Institute of Technology and the University of Chicago, any reduction of funds will have long-term consequences. Professor Linus Pauling summed up the scientists' view when he said at the meeting, "If these cuts are made in the budget even for one year, the whole economy will suffer for years to come."

No matter how large the forthcoming budget cuts are, many projects are already being disbanded. A survey carried out recently by the New York Times indicated a general mood of pessimism and bewilderment in university research facilities throughout the country. Physics and astronomy are the areas hardest hit, and a major factor is the cutback in programmes of the National Aeronautics and Space Agency. The Pilgrim Explorer Satellite project at Harvard University has just been cancelled after three years and expenditure of $\$ 1.25$ million. NASA has been forced gradually to terminate its "sustaining university programme", supporting graduate students in fields related to space research. The programme has been reduced from $\$ 100$ million to $\$ 10$ million in two years, and the number of grants from 1,300 to 50 since 1966, with no new grants expected for 1969 .

At the same time as the NASA cutbacks, the Defense Department had had to reduce drastically the funds allocated to basic research because of budget cuts and the practical priorities of the Vietnam war, causing a drop of $\$ 30$ million, or 9 per cent, in support of universities in the last fiscal year. Sixteen per cent of physicists in a recent American Institute of Physics survey reported they had lost all government support last year, and the figure is expected to rise to 21 per cent next year. Cuts include support from the Defense Department for radio astronomy at California Institute of 'Technology, University of California, University of Michigan, and the Arecibo Observatory in Puerto Rico.

The going is likely to be especially tough for graduate and post-doctoral students. The total number of scientists has increased by 20 per cent since 1965, and the competition for money and research posts is becoming increasingly severe. Federal pre-doctoral fellowships and traineeships were down by 18 per cent this year, and as long-range projects become more and more uncertain, research workers are unwilling to take on more graduate students. This is the most immediate cause for alarm for many scientists - a flow of new talent into the system must be maintained even if experimonts are postponed for a few years.

The biomedical field has not been as hard hit as the physical sciences, but is beginning to feel the coming squecze. About 40 per cent of all university rescarch funds comes through the National Institutes of Health, but support has levelled off recently, at about $\$ 1,000$ million. There has always been a slight increase, but nothing to compare with the 15-30 per cent growth rate before 1964. "For the first time last year we had extensive shortages of funds as contrasted to approved projects," Dr James A. Shannon, head of the institute, told the New York Times. Many grants are being approved, but even high priority does not guarantee payment, and even when funds do arrive it is often only after long delays. Medical schools are faring no better. At the Massachusetts General Hospital, affiliated with the medical school of Harvard University, a \$1 million study of computer use in hospitals has been cut by twothirds, a project to carry medical care into the slums is in jeopardy and the renovation of the hospital's research building has been deferred. "We may have our own type of poor people's march-and I'll be leading it," commented Dr John H. Knowles, director of Massachusetts General Hospital.

\section{Training Mathematicians}

SHould mathematicians spend more time in laboratories and less in their studics composing elegant proofs ? A recent Royal Society report on postgraduate training in applied mathematics, by a committee chaired by Professor M. J. Lighthill of Imperial College, thinks so. The committee concluded that all postgraduate students in this field should be exposed to some period of practical research in one field of applied 
mathematics and, concurrently, that more universities should develop major research schools in at least one specialized branch of applied mathematics.

The committee, which appears to have reached its conclusions independently of any outside opinions or surveys of students or researchers in the field, felt that far too many students and staff remained divorced from practical work in their fields. While undergraduates should spend at least two years studying a mixed course in pure and applied mathematics, both to give them a firm grounding in mathematical reasoning and to give them time to decide in what area they wish to concentrate, the committee emphasized that those students interested in applied mathematics should be aware of the practical aspects of at least one special field of application. To this end, there should be closer cooperation between the mathematics department and science, engineering and other departments at the university. Students should be encouraged to work on problems outside their own department, possibly in government or industrial laboratories, during the vacations.

Two members of the council of the Royal Society, Professor D. G. Kendall of Churchill College, Cambridge, and Professor C. A. Rogers of University College, London, dissented from the committee's strong emphasis on practical work and put forward a more modest view in an appendix to the report. They point out that it is often not practical to draw a line between "pure" and "applied" mathematics and that repeated interchanges between the two should be encouraged. With this in mind they stress that a general education in "pure" mathematics, even for those students who are primarily interested in mathematical applications, should continue beyond the first two undergraduate years. They also believe that technical proficiency is not a necessary criterion and that many students are so incompetent at technical work they would be deterred from studying for a postgraduate degree if practical work was required. While they agreed that in many instances practical research was useful, they concluded that experimental work for postgraduate applied mathematicians should never be compulsory.

Parallel to its study of graduate training, the committee looked at the research schools in applied mathematics at British universities and colleges. A survey of fifty-one institutions indicated that only nineteen had adequate "major" research schools in at least one branch of applied mathematics. The report concluded that every university should turn at least one minor school into a major one by concentrating resources in that one field and strengthening links with research in other university departments. But the committee was happy to find that topics covered were not unduly unbalanced and there were only two fields at present where the lack of a major research school was deemed harmful-control theory and general statistical mechanics and physics. Both of these fields were covered by minor research schools at six institutions, but none were sufficiently developed, according to the standards of the report.

This report is the fourth in a Royal Society series covering postgraduate training in the United Kingdom. Reports of the committees on chemistry, physies and biology have been published within the past year and engineering and earth sciences are still to come. Interesting and informative though this present report is, it is far too limited in its scope; it is unfortunate that the committee neglected to seek the opinions of people in the field and failed to coordinate its work with that of the other committees. A comprehensive study of postgraduate scientific training in Britain would have been more welcome; let us hope that the two remaining reports go some way to answering this need.

\section{Drug's Loss, Health's Gain}

THE new Secretary of Health, Education and Welfare in Washington has President Johnson's blessing for dramatic changes in the organization of his sprawling department. Not that HEW is to be split into three parts, which might be the best idea. (The US Govern. mental Manual of government organization needs four pages to list, in fine print, the names of the senior officials with responsibility for the federal government's programmes in the widely scattered and barely related fields of education, medical research and social benefits.) The department's responsibilities will remain enormously, almost derisorily wide. But the two biggest changes to be noticed immediately are the demotion of that excellent agency, the Food and Drug Administration, and the realization that policy-making, on a national level, is what American health and welfare needs most.

The man at the top, Mr Wilbur Cohen, has already been named by President Johnson as his leading adviser on health and welfare problems. That may sound like labelling the obvious but-assuming that the President listens to the advice-it means that America's domestic social problems are now being weighed at the White House with something like the gravity of defence or science. Perhaps there is more to rejoice at in the news that $\mathrm{Mr}$ Cohen will lead a new Interdepartmental Health Policy Council. It is intended to have the status of the President's Council of Economic Advisers (which has just succeeded in persuading a most unwilling Congress to vote for a rise in taxes in an election year). The kind of issue which the council will take up is the maldistribution of doctors and hospitals among the American population, the Negro and the rural getting far less than a fair share.

Whether the shake-up will be good for the crusading Food and Drug Administration remains to be seen. The FDA, from which the director, Dr James Goddard, resigned a few weeks ago, gets transferred to a new service which is to be created within the Public Health Service (which, led by the Surgeon General, is under the HEW department's jurisdiction). The new entity is to have the clumsy title of Service for Consumer Protection and Environmental Health. As well as food and drug regulation, it will supervise various national centres for radiological health, control of pollution in the air, urban and industrial health, and communicable diseases. In the bureaucratic jungle of HEW, therefore, the Consumer Protection Service will be on a par with the National Institutes of Health: both are subordinate to the Public Health Service. Until now, the FDA, which kept thalidomide from being approved for sale in the United States and which now is on a most relentless drive to force harmful or useless medicines off American shelves, had operated more or less independently. There is even talk that, for efficiency's sake, FDA might someday be killed off 